\title{
Intestinal perforation in necrotizing enterocolitis: Does cardiac surgery make a difference?
}

\author{
(ㄷ) Elif Altınay Kırlı, M.D., ${ }^{1}$ 단 Saniye Ekinci, M.D. ${ }^{2}$
}

${ }^{1}$ Department of Pediatric Surgery, Division of Pediatric Urology, Bursa City Hospital, Bursa-Turkey

${ }^{2}$ Department of Pediatric Surgery, Hacettepe University Faculty of Medicine, Ankara-Turkey

\begin{abstract}
BACKGROUND: The aim of this study is to evaluate the patients with intestinal perforation secondary to necrotizing enterocolitis (NEC) following cardiac surgery in the terms of risk factors and diagnosis/treatment process.

METHODS: A series of cases operated for intestinal perforation secondary to NEC were retrospectively reviewed in two groups. Group I involved patients who had cardiac surgery for congenital heart disease previous to intestinal perforation secondary to NEC. Group II consisted patients who had intestinal perforation secondary to NEC without any previous cardiac surgery. Demographic characteristics, prenatal and postnatal features, and pre- and post-operative course of groups were statistically compared to define differences.
\end{abstract}

RESULTS: Thirty-two patients underwent laparotomy secondary to intestinal perforation in this period. The gestational age and birth weight were smaller in Group II $(p=0.00$ I, $p=0.00$ I). Intrauterine growth retardation was more frequent in Group II $(p=0.05)$. More Group I patients had hypotensive periods $(p=0.018)$ before the diagnosis of NEC. Prostaglandin treatment and requirement of renal replacement therapy were more frequent in Group I $(p=0.022, p=0.03)$. The mortality rate was higher in Group I ( $p=0.018)$. All patients in Group I were late stage NEC at the time of diagnosis.

CONCLUSION: NEC developing after cardiac surgery is different from NEC seen in the neonatal period in the terms of etiology, facilitating factors, and clinical course. Mortality rate is higher in NEC after cardiac surgery. The diagnosis of intestinal perforation might be difficult in NEC after cardiac surgery due to insignificant physical examination findings and characteristic radiological signs of NEC. The history of prostaglandin usage and requirement of renal replacement were thought as alarming signs in terms of possible intestinal complications after cardiac surgery.

Keywords: Cardiac surgery; congenital heart disease; intestinal perforation; necrotizing enterocolitis.

\section{INTRODUCTION}

Necrotizing enterocolitis (NEC) is a gastrointestinal emergency that requires emergency surgical intervention secondary to related complications in newborn period. ${ }^{[1]}$ The immature intestinal system of premature neonate is considered as an important predisposing factor for NEC. The underlying cause of NEC in these patients is mucosal injury, as a result of increased cytokine production caused by bacterial overgrowth. ${ }^{[I]}$

However, $7 \%$ of NEC cases occurred in term infants with congenital heart disease (CHD). ${ }^{[2]}$ Unlike premature newborn population, mesenteric hypoperfusion secondary to complex CHD is suggested to be responsible for NEC associated with CHD. ${ }^{[1,3]}$ Thus, NEC in premature newborns may be a different entity than the infants who underwent corrective surgery for CHD.

Intestinal perforation leading to systemic inflammatory response is an independent risk factor for mortality in NEC. Emergency surgical intervention should be the treatment of choice in patients who have stable hemodynamics. ${ }^{[4]}$ Recent studies reported that mortality has declined for infants with CHD who undergo palliative or corrective cardiac surgery.

Cite this article as: Altınay Kırlı E, Ekinci S. Intestinal perforation in necrotizing enterocolitis: Does cardiac surgery make a difference? Ulus Travma Acil Cerrahi Derg 2021;27:662-667.

Address for correspondence: Elif Altınay Kırlı, M.D.

Bursa Şehir Hastanesi, Çocuk Cerrahisi Kliniği, Çocuk Ürolojisi Bilim Dalı, Bursa, Turkey

Tel: +90 224 - 9750000 E-mail: dr.elif@gmail.com

Ulus Travma Acil Cerrahi Derg 2021;27(6):662-667 DOI: 10.14744/tjtes.2020.80930 Submitted: 15.07.2020 Accepted: 28.08.2020

Copyright 2021 Turkish Association of Trauma and Emergency Surgery 
The advanced cardiac surgical procedures and increased ICU follow-up quality are mostly associated with this decline. However, intestinal complications related with the mesenteric hypoperfusion are still an important factor on the survival rate of the patients.

The information about NEC in neonates with low birth weight is extensive, while the data about NEC after cardiac surgery and the effect of the gastrointestinal complications on the mortality was limited in the existing literature. The primary aim of the presented study was to define the difference of risk factors, clinical features and outcomes related with intestinal perforation secondary to NEC after cardiac surgery from the others. We suggest that NEC following cardiac surgery has different etiology and different diagnostic course from the classical NEC of newborn period.

\section{MATERIALS AND METHODS}

All patients who were diagnosed and underwent laparotomy for intestinal perforation secondary to NEC in 16 years of period in our clinic were evaluated retrospectively. Patients with congenital gastrointestinal malformations and with incomplete medical information were excluded from the study.

Medical records of the patients included to study were reviewed for demographic features, prenatal history (intrauterine growth retardation and diagnosis of the cardiac defect), method of delivery, gestational features (Apgar Score (I-510. min), birth weight (low birth weight $<2500 \mathrm{~g}$, gestational week (prematurity $<37$ weeks), gastrointestinal system related complaints (feeding intolerance and vomiting), physical examination findings, nutritional characteristics (formula feeding, breast feeding, and mixed feeding), minor and major surgical interventions (umbilical vein catheterization, open cardiac surgery, and features of intestinal surgery), post-operative course (history of cardiovascular resuscitation and hypotensive periods, requirement of mechanic ventilation, and renal replacement therapy), and the long-term outcome (development of stricture, recurrent NEC, and short bowel syndrome).

Patients who require previous surgical intervention for $\mathrm{CHD}$ were regarded as Group I. Group II consisted of the patients who were diagnosed NEC during their postnatal neonatal intensive care unit (ICU) follow-up and newborns who were readmitted for NEC. All patients in Group I were followed in
ICU from the diagnosis of existing cardiac defect. All patients in Group II were followed up in ICU from the time of NEC diagnosis. NEC was staged according to the criteria originally proposed by Bell. ${ }^{[5]}$ All patients received similar interventional protocols including broad-spectrum antibiotic treatment, cessation of enteral feeding, nasogastric suction, and parenteral nutrition after the diagnosis of NEC. Laparotomy was performed when intestinal perforation suspected according to radiological or clinical findings during follow-up.

All clinical data were analyzed using SPSS 13.0 for significant differences. Normally distribution data are described as the means \pm standard deviations and were analyzed using Student $t$ test. Skewed data are described as medians and interquartile ranges and were analyzed using the Mann-Whitney $U$ test. Categorical data were analyzed using the Chi-square or Fisher's Exact Test. $\mathrm{P}<0.05$ was considered statistically significant. A written consent form was signed by the parents before the surgical interventions and the conduct of this study was approved by institutional ethics committee (number: 431.10-2777/20I2).

\section{RESULTS}

In this period, 164 children underwent open cardiac surgical procedures. Ten patients underwent explorative laparotomy for intestinal perforation (Group I, 33\%). CHD was diagnosed prenatally in seven (70\%) and postnatally in three patients (30\%). Transposition of great vessels $(n=4)$, tetralogy of Fallot $(n=2)$, hypoplastic left heart $(n=2)$, and coarctation of the aorta $(n=2)$ was the pre-operative cardiological evaluation and diagnosis of patients in Group I.

In the same period, 158 patients were diagnosed NEC and twenty patients (Group 2, 67\%) had intestinal perforation during postnatal ICU admission or during readmission for gastrointestinal symptoms. None of the patients in Group 2 had cardiac defect.

Demographic features of groups were similar on the base of gender (F/M: 1.3 in Group I and F/M: 0.75 in Group II, $p=0.48)$, method of delivery $(p=0.66)$, and APGAR scores after I, 5 , and 10 min later after delivery $(p=0.19, p=0.16$, and $p=0.81$, respectively). The rate of low birth weight, intrauterine growth retardation, and prematurity was higher in Group $2(p=0.00 I, p=0.05$, and $p=0.00 I)$. Characteristics of both groups are summarized in Table $I$.

Table I. Characteristics of both groups

\begin{tabular}{lccc}
\hline & Group I & Group 2 & p \\
\hline Gestational age (mean; weeks) & $38.50 \pm 1.04$ & $34.42 \pm 4.44$ & $0.00 I^{*}$ \\
Birth weight (mean; g) & $3530 \pm 452$ & $2192 \pm 784$ & 0.00 I $^{*}$ \\
Intrauterin growth retardation, n (\%) & $5(50)$ & $13(65)$ & $0.05^{* *}$ \\
\hline "T-test, ${ }^{* *}$ Chi-Square test. & & &
\end{tabular}


In Group I, cardiovascular system related cyanosis $(n=6,60 \%)$ and hemodynamic instability $(n=4,40 \%)$ were the main initial symptoms. Four patients in Group I underwent emergency cardiac surgery due to hemodynamic instability (40\%). The cardiopulmonary bypass and hypothermia during surgery was necessary in all children. Median duration of cardiac surgery was 330 $\pm 102 \mathrm{~min}$ and median duration of cardiopulmonary bypass was $163 \pm 39$ min duration of aortic clamp was $77 \pm 55$ min. Symptoms related to the gastrointestinal system were diagnosed during ICU follow-up after cardiac surgery. In general, main symptoms before the NEC diagnosis are hemodynamic instability not directly associated with cardiac status after cardiac surgery. However, the pathognomonic physical examination (abdominal distention, etc.) and clinical (bilious vomiting or feeding intolerance) or classical radiological signs of NEC (pneumatosis intestinal, portal venous gas) were not seen before the intestinal perforation. Laparotomy was performed immediately when intestinal perforation is suspected according to radiological finding of pneumoperitenoum in seven patients (lateral decubitus abdominal radiography in five and supine abdominal radiography in two) and observation of stool drainage from the dialysis catheter in three patients. Intestinal perforation was diagnosed median 2 days (range 0-3) after initial symptoms.
In Group II distention ( $n=12,60 \%)$, feeding intolerance $(n=4,20 \%)$ and biliary vomiting $(n=4,20 \%)$ were the main symptoms at the time of NEC diagnosis. The patients had Stage IB $(n=6,30 \%)$ IIB $(n=10,50 \%)$ and Stage IIA $(n=4$, $20 \%)$ NEC according to Bells classification at the time of NEC diagnosis. Initial gastrointestinal symptoms were detected median 6 days (range: 3-18 days) after enteral feeding and intestinal perforation was diagnosed median 8 days (range: 5-2l days) after initial symptom. Explorative laparotomy was performed after a time of follow-up period when the sign of advanced NEC or intestinal perforation was detected.

Risk factors associated with NEC were similar in groups except for the rate of hypotensive periods before the surgery $(p=0.018)$ and duration of mechanical ventilation was significantly longer $(p=0.022)$ in Group I. Risk factors associated with development of NEC in both groups are summarized in Table 2.

The age at intestinal surgery is younger in Group II $(p=0.003)$. Renal functions were deteriorated and renal replacement therapy was mostly required in Group I, just before the diagnosis of intestinal perforation ( $70 \%$ vs. $25 \%, p=0.03)$.

Table 2. Comparison of groups according to distribution of risk factors for NEC

\begin{tabular}{lccc}
\hline Risk factors & Group I & Group 2 & p \\
\hline Cardiopulmonary resuscitation, $\mathrm{n}(\%)$ & $5(50)$ & $9(45)$ & $0.6 \mathrm{I}^{*}$ \\
Hypotensive periods, $\mathrm{n}(\%)$ & $6(60)$ & $6(30)$ & $0.018^{*}$ \\
Umbilical vein catheterization, $\mathrm{n}(\%)$ & $4(40)$ & $10(50)$ & $0.46^{* *}$ \\
Enteral feeding before NEC diagnosis, $\mathrm{n}(\%)$ & & $8(40)$ & $0.49^{*}$ \\
$\quad$ Formula feeding & $5(50)$ & $11(1-30)$ & $0.022^{* * *}$ \\
$\begin{array}{l}\text { Mechanical ventilation/intubation } \\
\text { (mean duration; day) }\end{array}$ & $45(15-179)$ & \\
\hline
\end{tabular}

"Chi-square test, "Fisher's Exact test, " "Mann-Whitney U. NEC: Necrotizing enterocolitis.

Table 3. Surgical features of the patients

\begin{tabular}{lccc}
\hline & Group I & Group 2 & p \\
\hline $\begin{array}{l}\text { Age at intestinal surgery (median; days) } \\
\text { Distribution of involvement and perforation }\end{array}$ & $82(29-260)$ & $42(27-56)$ & $0.003^{* *}$ \\
$\quad$ lleum & $6(60)$ & $6(30)$ & $0.04^{*}$ \\
Colon & $4(40)$ & $10(50)$ & $0.18^{*}$ \\
Ileum and colon & $0(0)$ & $6(30)$ & N/A \\
Intestinal surgical approaches & & & N/A \\
Anastomosis & $2(20)$ & $4(20)$ & $0.16^{*}$ \\
Stoma & $6(60)$ & $13(65)$ & N/A \\
Intestinal anastomosis and stoma & $2(20)$ & $5(25)$ &
\end{tabular}


Mostly the ileum (60\%) was involved in Group I, and the colon (50\%) was in Group 2. Intestinal perforations were in involved areas. Operative findings and features of the surgical approaches are detailed in Table 3.

The use of prostaglandin was mostly required in Group I $(60 \%$ vs. $25 \%, p=0.022)$. Pre-operative inotropic medication (adrenaline) requirement was similar between groups $(80 \%$ vs. $60 \%, p=0.20$ ); however, post-operative inotropic medication (adrenaline) requirement was significantly higher in Group I ( $80 \%$ vs. 15\%, $p=0.00$ I). In addition, in post-operative period sedation (fentanyl; $n=4$, midazolam; $n=2$, and combine; $n=4$ ) and narcotic analgesic (morphine $n=8$ ) were used only in Group I.

In ICU follow-up, total enteral feeding after intestinal surgery was successful in three patients $\left(8^{\text {th }}, 9^{\text {th }}\right.$, and $12^{\text {th }}$ day) in Group I and 16 patients (median: 7 day; 4-14 days) in Group 2. None of the patients developed short bowel syndrome or have difficulties in enteral feeding after discharged in both groups. The mortality rate was significantly higher in Group I ( $n=7,70 \%$ vs. $n=4,20 \%, p=0.018$ ). The long-term follow-up of all patients in Group I was documented. Only one patient was survived and 5 years of follow-up period is uneventful, the other two died secondary to cardiogenic instability. The later follow-up of five patients were documented in Group 2 (median: 3 years, range: I-6 years). One patient underwent surgery due to colonic stenosis a year after primary surgery in Group 2.

\section{DISCUSSION}

Classically NEC is caused by mucosal injury secondary to the systemic response to the immature intestinal system in preterm babies with low birth weight. ${ }^{[6]}$ However, mesenteric hypoperfusion triggered by congenital cardiac anomalies and by hypotensive periods following surgeries for these anomalies has been reported to induce systemic response that disrupts the integrity of the mature intestinal system in infants, leading to NEC. ${ }^{[1,7]}$ In our study, the patients who underwent cardiac surgery were term infants with higher birth weights compared to those who were diagnosed for NEC in the neonatal period. The common reason for presentation of patients who underwent cardiac surgery was the symptoms related to congenital cardiac anomalies and, the findings of the intestinal system after cardiac surgery during hospitalization support different etiologies for the two groups.

Hypotensive periods were more frequently observed in cardiac surgical infants. However, it was found that they had exposed to many risk factors during treatment that trigger hypotension. Prostaglandin was used in before the cardiac surgery in patients in Group I. Prostaglandin is also associated with cardiogenic NEC due to apnea and hypotension episodes. ${ }^{[2,8]}$
It is known that cardiopulmonary bypass used during cardiac surgery and hypothermia induced during operation to protect vital organs cause hypoperfusion and disrupt intestinal permeability. ${ }^{[3,9,10]}$ In near half of the patients in our study, cardiopulmonary bypass was used under emergency conditions. In addition, the use of adrenaline in the post-operative period was higher compared to the group who had developed NEC in the neonatal period. Adrenalin used to achieve hemodynamic stability may be a factor contributing to NEC in this group of patients by causing splanchnic vasoconstriction. Therefore, the history of cardiac surgery is a risk factor for NEC, and the need for cardiopulmonary bypass, prostaglandin and adrenaline can be considered as factors increasing risk further.

Impaired systemic blood flow due to heart failure and hypotension results in renal failure after cardiac surgery. ${ }^{[8]}$ The requirement of renal replacement therapy is higher in infants who have undergone cardiac surgery. The requirement of dialysis emerged just before the appearance of the intestinal system symptoms. Therefore, the requirement of renal replacement therapy may be considered as an alert for surgery in patients with NEC.

Enteral feeding was generally unsuccessful in cardiac surgical infants. This observation may be related to the persisted hypoperfusion during intensive care follow-up or to the continued exposure to effects that may cause hypoperfusion, such as mechanical ventilation, adrenaline use, even if corrective cardiac surgery has been performed in patients.

It has been reported in the literature that the mortality rate of cardiogenic NEC is high. ${ }^{[1,12]}$ In our study, the mortality rate in cardiac surgical infants was significantly higher. This can be explained in two ways: First, post-operative follow-up is performed by sedation, analgesic, and mechanical ventilation in cardiac surgical infants, which may result in masking the examination findings and delaying the early diagnosis of NEC. In addition, generalized edema secondary to fluid overload may complicate the physical examination of the abdomen. The underlying problem is eliminated in neonatal NEC by surgery and appropriate medical treatment, but in the infants with cardiac surgery, hypoperfusion, which is the main cause of NEC, still exists in the post-operative period. This might be increasing the morbidity and mortality rate. Furthermore, cardiological comorbidities complicate the diagnostic process. The ascites secondary to cardiac decompression may overshadow the classical radiological findings of early staged NEC. The lateral decubitus abdominal radiography may be more useful for detecting pneumoperitoneum especially when there is a suspect of intestinal perforation in a patient with normal supine direct abdominal radiography.

The main results of the presented study are etiology of NEC after open cardiac surgery is multifactorial. Not only the etiopathogenesis but also the clinical course of NEC and diag- 
nostic steps of the intestinal perforations after open cardiac surgery are different. The previous studies about the NEC after cardiac surgery focused on the etiological differences especially the hypoperfusion. This is the first study that drawing attention to differences in the other risk factors and diagnostic challenges of intestinal perforation in NEC after cardiac surgery. Taking into consideration the risk factors mentioned in the study and following the patients in the terms of intestinal complications after the diagnosis of CHD may help early diagnosis of NEC. However, with these findings we cannot comment on the effect of early intervention before the intestinal perforation on mortality. Further studies should be plan if early diagnosis of NEC and surgical intervention before the perforation change the mortality rate.

The limitation of this study is the retrospective design and NEC after cardiac surgery in infancy is rare and our study has relatively small sample size. Even so this study gave us the opportunity to emphasize important risk factors and diagnostic challenges associated with intestinal perforation secondary to NEC in term infants, which still need to be investigated in large-scale prospective studies with the aim of reducing mortality rate.

\section{Conclusions}

Neonatal NEC and NEC following cardiac surgery have different etiological risk factors and different clinical presentations. Mortality rate is higher in NEC following cardiac surgery. The absence of classical radiological and physical examination findings does not rule out the diagnosis of NEC after cardiac surgery. The hemodynamic instability not directly associated with cardiac status, history prostaglandin usage, and requirement of renal replacement were thought as alarming signs in terms of possible intestinal complications after cardiac surgery.

Ethics Committee Approval: This study was approved by the Hacettepe University Ethics Committee (Date: 05.06.2012, Decision No: 431.10-2777/2012).

Peer-review: Internally peer-reviewed.
Authorship Contributions: Concept: S.E.; Design: S.E.; Supervision: S.E.; Resource: E.A.K.; Materials: E.A.K.; Data: E.A.K.; Analysis: E.A.K., S.E.; Literature search: E.A.K., S.E.; Writing: E.A.K.; Critical revision: S.E.

Conflict of Interest: None declared.

Financial Disclosure: The authors declared that this study has received no financial support.

\section{REFERENCES}

1. Giannone PJ, Luce WA, Nankervis CA, Hoffman TM, Wold LE. Necrotizing enterocolitis in neonates with congenital heart disease. Life Sci 2008;82:341-7. [CrossRef]

2. McElhinney DB, Hedrick HL, Bush DM, Pereira GR, Stafford LE, Gaynor JW, et al. Necrotizing enterocolitis in neonates with congenital heart disease: Risk factors and outcomes. Pediatrics 2000;106:1080-7. [CrossRef]

3. Malagon I, Onkenhout W, Klok M, van der Poel PF, Bovill JG, Hazekamp MG, et al. Gut permeability in neonates after a stage 1 Norwood procedure. Pediatr Crit Care Med 2005;6:547-9. [CrossRef]

4. Pierro A, Hall N. Surgical treatments of infants with necrotizing enterocolitis. Semin Neonatol 2003;8:223-32. [CrossRef]

5. Bell M.J. Necrotizing Enterocolitis. N Engl J Med. 1978;298:5, 281-282.

6. Zani A, Pierro A. Necrotizing enterocolitis: controversies and challenges. F1000 Reserch 2015;4:1373. [CrossRef]

7. D'Acona G, Baillot R, Poirier B, Dagenais F, Ibarra JIS, Bauset R, et al. Determinants of gastrointestinal complications in cardiac surgery. Tex Heart Inst J 2003;30:280-285.

8. Byhahn C, Strouhal U, Martens S, Mierdi S, Mierdl S, Kessler P, Westphal K, et al. Incidence of gastrointestinal complications in cardiopulmonary bypass patients. World J Surg 2001;25:1140-1144. [CrossRef]

9. McSweeney ME, Gardwood S, Levin J, Mario MR, Wang SX, Kardatzke D, et al. Adverse gastrointestinal complications after cardiopulmonary bypass: can outcome be predicted from preoperative risk factors? Anesth Analg. 2004;98:1610-1617. [CrossRef]

10. Kargl S, Maier R, Gitter R, Pumberger W. Necrotizing enterocolitis after open cardiac surgery for congenital heart defects- a serious threat. Klin Padiatr 2003;225:24-28. [CrossRef]

11. Trompeter M, Brazda T, Remy CT, Vestring T, Reimer P et al. Non occlusive mesenteric ischemia: etiology diagnosis and interventional therapy. Eur Radiol 2002;12:1179-1187. [CrossRef]

12. Siano E, Lauriti G, Ceccanti S, Zani A. Cardiogenic necrotizing enterocolitis: A clinically distinct entity from classical necrotizing enterocolitis. Eur J Pediatr Surg 2019;29:14-22. [CrossRef] 


\section{ORİJINAL ÇALIŞMA - ÖZ}

\section{Nekrotizan enterokolite ikincil intestinal perforasyon: Kardiyak cerrahi sonrası seyri farklı mıdır? \\ Dr. Elif Altınay Kırlı, ${ }^{1}$ Saniye Ekinci ${ }^{2}$}

${ }^{1}$ Bursa Şehir Hastanesi, Çocuk Cerrahisi Kliniği, Çocuk Ürolojisi Bilim Dalı, Bursa

${ }^{2}$ Hacettepe Üniversitesi Tıp Fakültesi, Çocuk Cerrahisi Anabilim Dalı, Ankara

AMAÇ: Bu çalışmanın amacı kardiyak cerrahi geçiren hastalarda görülen nekrotizan enterokolite (NEC) ikincil sindirim kanalı perforasyonun etiyolojik farklılıklar, risk faktörleri, tedavi ve izleme ait özellikler açısından değerlendirilmesidir.

GEREÇ VE YÖNTEM: Nekrotizan enterokolite ikincil sindirim kanalı perforasyonu nedeni ile ameliyat edilen hastaların dosya bilgileri geriye dönük olarak değerlendirildi. Hastalar doğuştan kalp hastalığı nedeni ile kardiyak cerrahi uygulanması öyküsü temel alınarak iki gruba ayırıldı. NEC'ye ikincil sindirim kanalı perforasyonu kardiyak cerrahi sonrası izlemde gelişen hastalar Grup I'de kardiyak cerrahi girişim olmaksızın NEC'ye ikincil gelişen sindirim kanalı perforasyonları Grup 2'de toplandı. Gruplara ait demografik özellikler, pre ve postnatal takip özellikleri, uygulanan cerrahi girişimler, ameliyat öncesi ve sonrası izlem farklılıklar açısından istatistiksel olarak değerlendirildi.

BULGULAR: Belirtilen süre içerisinde 30 hastanın NEC'ye ikincil sindirim kanalı perforasyonu nedeni ile ameliyat edildiği tespit edildi. Prematürite, düşük doğum ağılığı ve intrauterin gelişme geriliği öyküsü Grup 2'de yer alan hastalarda daha sıktır ( $p=0.00 I, p=0.00 I, p=0.05)$. NEC tanısı öncesi hipotansif atak geçirme öyküsü Grup I'de yer alan hastalarda daha sıktır $(p=0.018)$. Prostaglandin kullanımı ve renal replasman tedavisi gereksinimi oranı Grup I'de yer alan hastalarda daha yüksek orandadır $(p=0.022$, $p=0.03)$. Grup I'de yer alan hastaların tamamında tanı anında NEC ileri evredir. Mortalite Grup I'de yer alan hastalarda daha yüksektir ( $\mathrm{p}=0.018)$.

TARTIŞMA: Kardiyak cerrahi sonrası gelişen NEC tablosu etiyoloji, kolaylaştıııı faktörler ve klinik seyir açısından yenidoğan döneminde görülen NEC'den farklıdır. Kardiyak cerrahi sonrası ortaya çıkan NEC'ye ikincil sindirim kanalı perforasyonunda mortalite oranı daha yüksektir. Bu grupta ayrıca NEC tanısının ve sindirim kanalı perforasyonun klinik olarak tespit edilmesi klasik NEC bulgularının baskılanması ve fizik inceleme bulgularının belirsizliği nedeni ile zordur. Kardiyak sağaltım esnasında prostaglandin kullanımı ve takipte renal replasman tedavisi gereksinimi olası sindirim sistemi preforasyonu gelişimi açısından uyarııı bulgulardır.

Anahtar sözcükler: Doğuştan kalp hastalı̆̆; kardiyak cerrahi; nekrotizan enterokolit; sindirim sistemi perforasyonu.

Ulus Travma Acil Cerrahi Derg 2021;27(6):662-667 doi: 10.14744/tjtes.2020.80930 